\title{
PENGEMBANGAN MEDIA PEMBELAJARAN INTERAKTIF BERBASIS CONTEXTUAL TEACHING AND LEARNING BIDANG STUDI PKn
}

\author{
Muhammad Yulfikar Akmal ${ }^{1}$, R. Mursid ${ }^{2}$,Abdul Munir ${ }^{3}$ \\ ${ }^{I}$ SMA Swasta AR-RAHMAN Medan \\ ${ }^{2}$ FT Universitas Negeri Medan, Sumatera Utara \\ yulfikarakmal@gmail.com
}

\begin{abstract}
Abstrak: Studi ini bertujuan untuk: (1) membantu siswa dalam belajar dengan menggunakan media pembelajaran interaktif berbasis CTL (2) mengetahui media pembelajaran interaktif berbasis CTL layak digunakan pada mata pelajaran PKn. Jenis penelitian ini adalah penelitian pengembangan yang menggunakan model pengembangan produk Borg dan Gall yang dipadu dengan model pengembangan pembelajaran Dick dan Carey. Model pengembangan produk pembelajaran ini merupakan model yang disusun secara terprogram dengan urutan yang sistematis dan memenuhi karakteristik siswa dalam belajar. Model ini meliputi enam tahapan, yakni: studi literatur, perencanaan atau desain pengembangan, pengembangan produk, validasi ahli, uji coba, revisi, produk akhir.Subyek uji coba terdiri dari dua ahli materi mata pelajaran Pendidikan Kewarganegaraan, dua ahli desain pembelajaran, dua ahli rekayasa perangkat lunak dan desain grafis, tiga siswa untuk uji perorangan, sembilan siswa untuk uji kelompok kecil, dan tiga puluh empat siswa untuk uji lapangan. Data tentang kualitas produk pengembangan ini dikumpulkan dengan angket. Data-data yang dikumpulkan dianalisis dengan teknik analisis deskriptif kualitatif. Hasil pengembangan media interaktif menunjukan validasi ahli menunujukkan bahwa keseluruhan rata-rata dikategorikan "Sangat Baik" dan uji kelayakan menunujukkan bahwa keseluruhan ratarata dikategorikan "Sangat Baik". Hasil pengujian hipotesis membuktikan bahwa terdapat perbedaan yang signifikan antara hasil belajar siswa yang dibelajarkan dengan menggunakan media pembelajaran interaktif Macromedia Flash dengan hasil belajar siswa yang dibelajarkan dengan pembelajaran konvensional.
\end{abstract}

Kata Kunci: Media Contextual Teaching and Learning, Hasil Belajar

Abstract: This study aims to: (1) help students learn by using Interactive Learning Media Based CTL. (2) know that Interactive Learning Media Based CTL feasible to use on civics lesson. This type of research is the development of research that uses models Borg and Gall product development combined with learning development model of Dick and Carey. This learning product development model is a model that is prepared in a programmed sequence of systematic and meet the characteristics of the students in learning. This model includes six stages, namely: literature studies, planning or design development, product development, validation expert, testing, revision, the final product. The subject of the trial consists of two subject matter experts Subjects Engineering Energy Conversion, two expert instructional design, two expert software engineering and graphic design, three students for the test individuals, nine students for small group test, and fifty-eight students for field testing. Data about the quality of the products of this development are collected by questionnaire. The data collected were analyzed using qualitative descriptive analysis techniques. The results of development of Interactive Learning Media by Experts' validation indicate that the overall average categorized "Very Good" And the Feasibility test indicate that the overall average categorized "Very Good". Hypothesis testing results show that there are significant differences between the students learning outcome that to be learned by using Macromedia Flash Interactive Learning Media and Students learn outcome to be learned by conventional learning.

Keywords: Media, Contextual Teaching and Learning, Learning Outcomes

\section{PENDAHULUAN}

Pada hakikatnya pendidikan bertujuan untuk meningkatkan sumber daya manusia (SDM), karena peningkatan SDM berkaitan dengan pembentukan manusia seutuhnya. Untuk itu perlu dilakukan berbagai usaha dalam rangka meningkatkan mutu pendidikan diberbagai lembaga dan institusi khususnya sekolah, 
dikarenakan sekolah memiliki andil yang besar dalam meningkatkan sumber daya manusia melalui proses belajar mengajar. Peningkatan mutu pendidikan pada jenjang sekolah harus lebih ditingkatkan untuk menghasilkan lulusanlulusan yang berkualitas dan mampu bersaing dalam dunia pendidikan. Disamping itu disiplin ilmu yang dipelajari harus memiliki materi cocok, menggunakan kurikulum yang sesuai dengan kebutuhan perkembangan zaman dan dalam penyampainnya hendaknya menggunakan strategi yang tepat sehingga dapat menumbuh kembangkan kreativitas dan keterampilan siswa untuk dapat memecahkan setiap permasalahan yang dihadapinya dalam kehidupan nyata.

Kemajuan yang pesat dibidang sains dan teknologi dunia saat ini menuntut pemerintah untuk lebih memperhatikan masalah pendidikan di Indonesia. Laju perkembangan ilmu pengetahuan, teknologi dan seni melampaui laju peningkatan kualitas sumber daya manusia Indonesia yang dianggap mampu bersaing dengan negara-negara luar.

Untuk meningkatkan minat siswa, guru dituntut untuk menjadikan pelajaran lebih menarik agar dapat mendorong siswa untuk belajar secara optimal, baik belajar mandiri maupun dalam pembelajaran di kelas dengan cara-cara yang dapat merangsang siswa baik kognitif, afektif serta psikomotoriknya, seperti dengan menampilkan alat peraga maupun media lainnya. Media merupakan salah satu komponen komunikasi, menurut Association for Education and Communication Teknology (AECT: 1986) media yaitu segala bentuk yang dipergunakan untuk sesuatu proses penyaluran informasi. Komunikasi memegang peranan penting dalam pembelajaran. Agar komunikasi antara guru dan siswa berlangsung baik dan informasi yang disampaikan guru dapat diterima siswa, guru perlu menggunakan media pembelajaran. Kegiatan proses pembelajaran menggunakan media dapat meningkatkan komunikasi antara guru dan siswa pada waktu berlangsungnya proses belajar mengajar terjadi.

Perkembangan teknologi multimedia yang ada pada masa kini mampu mendukung proses pembelajaran yang berdasarkan pendekatan dimana bisa diwujudkan dengan desain media pembelajaran yang adaptif dan menjanjikan dimasa depan sebagai paradigma pembelajaran baru dan juga mampu menyediakan ruang dengan alat bantu yang inovatif untuk memenuhi kebutuhan siswa dimana sebelumnya tidak mungkin dilakukan, keberadaan komputer yang telah meluas sampai tingkat sekolah dasar saat ini belum banyak digunakan untuk meningkatkan prestasi khususnya dalam pembelajaran. Selama proses pembelajaran, guru hanya mengandalkan metode ceramah (ekspositori) secara klasikal. Guru kurang menggunakan media pendukung selain buku. Metode pembelajaran seperti ini kurang memahami prinsip pembelajaran yang efektif dan kurang memberdayakan potensi siswa.

Kegiatan pembelajaran seharusnya mampu mengoptimalkan semua potensi siswa untuk menguasai semua kompetensi yang diharapkan. Proses belajar mengajar sebaiknya dilandasi dengan prinsip-prinsip berpusat pada siswa, mengembangkan kreativitas siswa, menciptakan kondisi yang menyenangkan dan menantang, mengembangkan beragam kemampuan yang bermuatan nilai, menyediakan pengalaman belajar yang beragam dan belajar dengan pengalaman langsung (learning to do).

$$
\text { Slavin (2003:65) menyatakan, }
$$

penerapan strategi pembelajaran yang tepat, menjadi pilihan bila menginginkan pembelajaran lebih efektif dan efisien agar siswa dapat belajar dengan baik maka strategi pembelajaran dilakukan secara efektif dan efisien. Dikatakan efektif bila strategi pembelajaran tersebut menghasilkan sesuai dengan yang diharapkan atau dengan kata lain tujuan tercapai. Dikatakan efisien apabila strategi pembelajaran yang diterapkan relatif menggunakan tenaga, usaha, biaya dan waktu yang dipergunakan seminimal mungkin.

Untuk itulah dalam penyelenggaraan pendidikan di sekolah, tentunya siswa diberikan berbagai materi pelajaran yang harus dikuasai siswa sesuai dengan tujuan yang diharapkan. Salah satu materi pelajaran yang disampaikan itu adalah Pancasila dan Kewarganegaraan (PKn). PKn merupakan mata pelajaran yang mengarah kepada pembentukan kepribadian dan wujudnya terlihat dalam perilaku keimanan dan ketakwaan terhadap Tuhan Yang Maha Esa, perilaku etika dan moral serta rasa tanggung jawab kenegaraan dalam diri siswa. Menurut Deni (2015:14) umumnya materi yang ada pada PKn terdiri dari nilai, norma dan peraturan hukum yang mengatur perilaku warga negara, sehingga dengan itu semua diharapkan kepada peserta didik dapat mengamalkan, mensosialisasikan 
dan mengimplementasikan materi-materi tersebut dalam kehidupan sehari-hari yang bakal menjadi sebuah karakter pribadi yang melekat pada setiap individu peserta didik.

Pengembangan multimedia minimal menguasai: desain komunikasi, penyuntingan video, fotografi, grafik layout, desain grafis dan desain komunikasi visual serta teknologi komputer. Teori teknologi pendidikan menyediakan petunjuk untuk mendesain program multimedia yang hendak dicapai oleh pembelajar. Multimedia interaktif dalam pembelajaran dapat memberikan jawaban atas suatu bentuk pembelajaran yang menggunakan pendekatan secara tradisional dimana pendekatan tersebut cenderung teacher centered dan kurang interaktif. Multimedia interaktif meningkatkan antarmuka komputer text only minimalis dan menghasilkan keuntungan yang memuaskan dengan mencari dan menarik perhatian, sekaligus ketertarikan dapat memperkuat ingatan.

Pada penerapannya, media interaktif Macromedia Flash berbasis CTL pada bidang studi PKn yang bakal direncanakan nanti akan menghadirkan beberapa tampilan yang berbeda dengan mengakomodasi seluruh fasilitas dari macromedia flash itu sendiri seperti animasi, fitur-fitur yang elegan, audio serta video yang bakal dikemas dengan menarik, sehingga pembelajaran akan lebih menarik untuk disajikan kepada siswa dengan materi Globalisasi. Pada materi Globalisasi akan menampilkan gambar-gambar yang sangat menarik serta tampilan dua dimensi apalagi isi materi tersebut (Globalisasi) sangat membantu siswa dalam meningkatkan daya kognitif siswa untuk melihat perkembangan globalisasi agar lebih mudah diserap oleh siswa itu sendiri sekaligus mengaplikasikannya dalam kehidupan sehari-hari.

Adapun keunggulan dari macromedia flash 6 dalam pembelajaran ini adalah, (1) media flash memiliki keunggulan sendiri dari programprogram media interaktif lainnya serta memuat (dapat diisi) dengan segala program yang ada dikomputer, seperti membuat audio, vidio, aplikasi powerpoint, menampilkan tampilan dua dimensi, mengimport dari berbagai jenis aplikasi. (2) pembelajaran yang ditampilkan dengan macromedia flash 6 akan lebih menarik dan menimbulkan inspirasi bagi yang melihatnya apalagi pembelajaran yang diinginkan sesuai dengan tujuan yang dicapai.
(3) siswa lebih proaktif dalam pembelajaran pada macromedia flash 6 karena dapat menimbulkan penasaran serta keingin tahuan dalam menganalisis. (4) guru akan termotivasi jika sudah mampu menjalankan program macromedia flash 6 untuk terus menerus dalam setiap materi pembelajaran.

Digunakannya macromedia flash 6 dalam peneliti ini, banyak guru-guru yang masih asing akan aplikasi ini, untuk itu perlu dianggap hal yang tidak asing jika aplikasi ini dapat disosialisasikan kepada guru-guru agar lebih proaktif dalam membuat bahan pembelajaran secara interaktif, proaktif dan professional, sebab jika tidak dimulai, akan membuat sebuah "keterasingan" terhadap aplikasi teknologi pembelajaran yang begitu mendukung kepada kecerdasan siswa dalam pembelajaran.

Untuk mengatasi berbagai permasalahan dalam pelaksanaan pembelajaran diatas, dibutuhkan juga suatu model pembelajaran yang lebih efektif dan inovatif dalam merangsang dan membuat peserta didik lebih aktif selama pembelajaran berlangsung, dengan menggunakan pendekatan CTL sekaligus membuat siswa mampu mengkaitkan antara materi pelajaran yang diajarkan dengan situasi dunia nyata peserta didik dan mendorong peserta didik membuat hubungan antara pengetahuan yang dimilikinya dengan penerapannya dalam kehidupan sehari-hari.

Masalah penelitian dirumuskan sebagai berikut: (1) apakah media pembelajaran interaktif berbasis CTL dengan macromedia flash 6 yang dikembangkan dapat membantu siswa dalam belajar? (2) apakah media pembelajaran interaktif berbasis CTL dengan macromedia Flash 6 layak digunakan pada mata pelajaran PKn?

METODE

Penelitian ini dilaksanakan di SMA ArRahman Medan dan pelaksanaannya dilakukan pada semester genap tahun pelajaran 2015/2016. Populasi penelitian ini adalah seluruh peserta didik kelas XII SMA Ar-Rahman Medan Tahun Pelajaran 2015/2016 yang berjumlah 34 orang.

Penelitian ini menggunakan metode pengembangan. Model pengembangan yang digunakan dalam mengembangkan media pembelajaran ini adalah model pengembangan Borg and Gall (1983) yang dipadu dengan model pengembangan pembelajaran Dick dan Carey (2005). Untuk menguji keefektifan produk dilakukan uji t dua pihak. 


\section{HASIL PENELITIAN DAN PEMBAHASAN}

Penelitian pengembangan ini dilakukan dengan langkah-langkah sebagai berikut: (1) Melakukan penelitian pendahuluan, yang meliputi: (a) Identifikasi kebutuhan pembelajaran dan menentukan standar kompetensi mata pelajaran (b) Melakukan analisis pembelajaran (c) Mengidentifikasi karakteristik dan perilaku awal peserta didik (d) Menulis kompetensi dasar dan indikatornya (e) Menulis tes acuan patokan dan menyusun strategi pembelajaran. (2) Pembuatan desain software, meliputi: (a) pembuatan naskah (b) pembuatan storyboard (c) pembuatan Flowchart View. (3) Pembuatan bahan, yang meliputi: (a) pembuatan dan pengumpulan gambar (image) dan animasi, (b) perekaman dan pengumpulan audio. (4) Mengembangkan dan membuat media pembelajaran interaktif (5) Review dan uji coba produk (6) Uji keefektifan produk.

Validasi produk oleh pakar media, ahli materi dan desain pembelajaran. Uji coba perorangan/one-to-one evaluation oleh 3 siswa kemampuan rendah, sedang dan tinggi. Uji kelompok kecil / small group evaluation oleh 9 orang siswa. Uji coba lapangan /Field trial evaluation berjumlah 34 Siswa. Persentase ratarata hasil penilaian terhadap media pembelajaran interaktif mata pelajaran konversi energi dapat dilihat pada Tabel 1.

Tabel 1. Rangkuman Persentase Rata-Rata Hasil Penilaian Terhadap Media Pembelajaran Interaktif Pada Materi Dampak-dampak Globalisasi

\begin{tabular}{|c|c|c|c|}
\hline No & Responden & $\begin{array}{c}\text { Persentase } \\
\text { Rata-rata }\end{array}$ & Kriteria \\
\hline 1 & Ahli materi & $95,00 \%$ & $\begin{array}{l}\text { Sangat } \\
\text { Baik }\end{array}$ \\
\hline 2 & $\begin{array}{l}\text { Ahli desain } \\
\text { pembelajaran }\end{array}$ & $91,96 \%$ & $\begin{array}{l}\text { Sangat } \\
\text { Baik }\end{array}$ \\
\hline 3 & $\begin{array}{l}\text { Ahli rekayasa } \\
\text { perangkat lunak }\end{array}$ & $94,00 \%$ & $\begin{array}{l}\text { Sangat } \\
\text { Baik }\end{array}$ \\
\hline 4 & $\begin{array}{l}\text { Siswa pada uji } \\
\text { coba perorangan }\end{array}$ & $86,90 \%$ & $\begin{array}{l}\text { Sangat } \\
\text { Baik }\end{array}$ \\
\hline 5 & $\begin{array}{l}\text { Siswa pada uji } \\
\text { coba kelompok } \\
\text { kecil }\end{array}$ & $85,10 \%$ & $\begin{array}{l}\text { Sangat } \\
\text { Baik }\end{array}$ \\
\hline \multirow[t]{2}{*}{6} & $\begin{array}{l}\text { Siswa pada uji } \\
\text { coba lapangan }\end{array}$ & $88,20 \%$ & $\begin{array}{l}\text { Sangat } \\
\text { Baik }\end{array}$ \\
\hline & Rata-Rata & $90,13 \%$ & $\begin{array}{l}\text { Sangat } \\
\text { Baik }\end{array}$ \\
\hline
\end{tabular}

Hasil penelitian terhadap media pembelajaran interaktif mata pelajaran PKn pada validasi ahli dan uji coba di kelas XII SMA
Swasta Ar-Rahman Medan menunjukkan bahwa produk yang dikembangkan sangat baik/layak digunakan pada pembelajaran PKn di SMA Swasta Ar-Rahman Medan.

Pengujian efektivitas dilakukan dengan langkah awal pada kedua kelas sampel sebelum memberikan perlakuan yang berbeda adalah dengan memberikan tes awal kepada siswa untuk mengetahui kemampuan awal masingmasing siswa kedua kelas. Kemudian, melakukan pembelajaran yang berbeda yaitu kelas eksperimen dengan media pembelajaran multimedia interaktif macromedia flash berbasis CTL dan kelas kontrol dengan pembelajaran konvensional yang menggunakan multimedia slide Power Point 2013. Kemudian pada akhir proses pembelajaran akan diberikan tes akhir untuk mengetahui hasil belajar siswa. Berdasarkan penelitian maka diperoleh hasil test awal (pre-test) dan test akhir (post-test) untuk kedua kelompok sampel yaitu masing-masing kelompok eksperimen dan kontrol 34 orang siswa.

Diperoleh nilai rata-rata nilai pre-test kelas eksperimen sebesar 52,20 dengan nilai tertinggi 75 dan nilai terendah 37,5 serta simpangan baku 8,09 sedangkan untuk rata-rata nilai postes sebesar 85,15 dengan nilai tertinggi 100 dan nilai terendah 75,00 serta simpangan baku 6,30. Nilai rata-rata nilai pre-test kelas kontrol sebesar 51,62 dengan nilai tertinggi 87,50 dan nilai terendah 65,00 serta simpangan baku 10,28 sedangkan untuk rata-rata nilai postes sebesar 76,91 dengan nilai tertinggi 98 dan nilai terendah 75 serta simpangan baku 6,30.

Sebelum melakukan uji $t$, data terlebih dahulu diuji normalitas dan homogenitas nya. Hasil pengujian normalitas data dilakukan dengan uji Lilifors, adapun hasil pengujian adalah sebagai berikut:

\section{Tabel 2. Hasil Uji Normalitas Data}

\begin{tabular}{|c|c|c|c|c|}
\hline Data & Kelas & $\mathbf{L}_{\text {hitung }}$ & $\mathbf{L}_{\text {tabel }}$ & Ket. \\
\hline \multirow{2}{*}{ Pretes } & Eksperimen & 0,133 & 0,190 & Normal \\
\hline & Kontrol & 0,123 & 0,190 & Normal \\
\hline \multirow{2}{*}{ Postes } & Eksperimen & 0,098 & 0,190 & Normal \\
\hline & Kontrol & 0,128 & 0,190 & Normal \\
\hline
\end{tabular}


Tabel 3. Hasil Uji Homogenitas Data

\begin{tabular}{cccc}
\hline Data & F hitung & F tabel & Keterangan \\
\hline Pretes & 3,453 & 3,49 & Homogen \\
Postes & 0,729 & 3,49 & Homogen \\
\hline
\end{tabular}

Dari hasil uji prasyarat kedua kelas dinyatakan berdistribusi normal dan homogen, untuk itu dapat dilakukan uji t sebagai uji efektivitas media pembelajaran. Adapun hasil pengujian adalah sebagai berikut:

Tabel 4. Hasil Uji t dua pihak

\begin{tabular}{cccc}
\hline Data & $\mathbf{t}_{\text {hitung }}$ & $\mathbf{t}_{\text {tabel }}$ & Keterangan \\
\hline Postes HB & 5,75 & 2,02 & Ha diterima \\
\hline
\end{tabular}

Dapat dilihat bahwa pada kedua kelas $t$ hitung $\geq \mathrm{t}_{\text {tabel }}$ sehinga dapat disimpulkan bahwa pembelajaran menggunakan media pembelajaran interaktif Macromedia Flash lebih baik dari konvensionalnya pada taraf signifikansi $(\alpha=0,05)$.

\section{PEMBAHASAN}

1. Pembahasan Hasil Penelitian Pegembangan Produk

PKn merupakan salah satu ilmu yang dalam mempelajarinya memerlukan kajian yang luas dan mendalam sehingga diperlukan suatu media untuk memudahkan dalam memahaminya. Media pembelajaran ini disusun dengan macromedia flash yang memiliki kemampuan animasi yang interaktif, selain itu dapat mengimpor gambar dan animasi dari program lain sehingga media yang dihasilkan lebih menarik bila dipandu dengan macros. Media yang dikembangkan adalah media interaktif. Jadi akan ada penggabungan antara suara, gambar, video, tulisan animasi dan macros.

Selanjutnya waktu dan ruang bukan masalah bagi proses pembelajaran dimanapun kapanpun dan siswa dapat berkomunikasi baik pertanyaan, pendapat, tanggapan dan sebagainya, dalam hal ini siswa lebih dituntut dalam melakukan pembelajaran dengan menggunakan inquiry, menguraikan, serta bersosialisasi dalam melaksanakan berbasis CTL yaitu: Konstruktivisme, Tanya jawab, Inkuiri, Komunitas belajar, Pemodelan, Refleksi, Penilaian otentik.

Produk pengembangan media pembelajaran interaktif pada mata pelajaran Pendidikan Kewarganegaraan materi Dampakdampak Globalisasi merupakan materi pembelajaran yang telah dikembangkan dengan memperhatikan aspek pembelajaran dan media sebagai prinsip desain pesan pembelajaran. Penelitan pengembangan produk yang dilakukan ini diarahkan untuk menghasilkan suatu produk berupa media pembelajaran interaktif pada materi Dampak-dampak Globalisasi untuk siswa SMA swasta AR-RAHMAN Medan semester II (genap) yang digunakan untuk meningkatkan proses pembelajaran maupun kompetensi siswa. Oleh sebab itu proses penelitian ini dilakukan dan diawali dengan, (1) studi pendahuluan, (2) kemudian mendesain media pembelajaran, (3) melakukan validasi produk dan melakukan revisi dan penyempurnaan berdasarkan analisis data validasi dari ahli materi, (4) ahli desain pembelajaran dan ahli rekayasa perangkat lunak yang dilanjutkan dengan uji coba perorangan, uji coba kelompok kecil, dan uji coba lapangan sehingga dihasilkan media pembelajaran yang layak digunakan sesuai dengan karakteristik mata pelajaran dan siswa sebagai pengguna. Hal ini sejalan dengan pendapat Borg dan Gall (1983:772) pada buku Education Research an Introduction yang mengemukakan bahwa penelitian pengembangan adalah penelitian yang berorientasi untuk mengembangkan dan memvalidasi produk-produk yang digunakan dalam pendidikan.

Aspek yang direvisi dan disempurnakan berdasarkan analisis data dan uji coba serta masukan dari ahli materi, ahli desain pembelajaran, ahli rekayasan perangkat lunak dan siswa selaku pengguna media pembelajaran interaktif ini, bertujuan untuk menggali beberapa aspek yang lazim dalam proses pengembangan suatu produk. Variabel-variabel media pembelajaran memiliki nilai rata-rata "Sangat Baik". Adapun variabel media pembelajaran yang dinilai meliputi kelayakan isi, penyajian, kebahasaan, pemrograman, dan kegrafikan.

Beberapa kegunaan dan manfaat dalam penggunaan media pembelajaran interaktif pada materi Dampak-dampak Globalisasi sebagai berikut: (1) materi mudah dipahami karena konsep yang disajikan direncanakan untuk mempermudah siswa dan sistematis, (2) media pembelajaran interaktif memberi kesempatan siswa untuk belajar sesuai dengan kecepatan masing-masing individu, (3) belajar lebih cepat dan menarik sehingga tidak menimbulkan kebosanan karena dilengkapi dengan gambargambar dan animasi yang bervariasi. (4) adanya 
kesempatan dalam mengkonstruksikan kogintif dengan proses Contextual Teaching and Learning, siswa dapat melakukan proses konstrutivisme, inkuiri, bertanya, komunitas belajar dan refleksi selama pembelajaran (5) media pembelajaran interaktif ini juga dapat digunakan sebagai alternatif media pembelajaran secara konvensional maupun individual.

2. Pembahasan Hasil Penelitian Uji Efektifitas Produk

Untuk memperoleh media pembelajaran yang efektif, dan berdaya tarik, peneliti menggunakan prinsip desain pembelajaran dan desain media dalam mengembangkan media pembelajaran interaktif. Media pembelajaran yang dikembangkan berdasarkan masukan pada kegiatan analisis kebutuhan untuk memperoleh informasi bahwa media pembelajaran interaktif yang dikembangkan memang dibutuhkan dan dapat memberi kemudahan bagi peserta didik dan guru sebagai user.

Sebuah media bisa dikatakan Layak setelah memperlihatkan hasil yang memuaskan dalam mencapai tujuan yang telah ditentukan. Dalam hal ini, maka dilakukanlah uji coba produk pada proses pembelajaran untuk mengetahui efektifitas pembelajaran. Efektifitas media itu, didapat dari nilai hasil belajar siswa. Miarso (2011:536) indikator untuk menentukan efektivitas dalam proses pembelajaran adalah : (a) pengorganisasian materi yang baik, (b) komunikasi yang efektif, (c) penguasaan dan antusiasme terhadap materi pelajaran, (d) sikap positif terhadap siswa, (e) pemberian nilai adil, (f) keluwesan dalam pendekatan pembelajaran, dan (g) hasil belajar siswa yang baik.

Hasil pengolahan data penelitian yang dilakukan, terdapat perbedaan hasil belajar Pendidikan Kewarganegaraan antara siswa yang dibelajarkan dengan menggunakan media pembelajaran interaktif dan siswa yang dibelajarkan dengan pembelajaran konvensional yaitu rata-rata hasil belajar siswa yang dibelajarkan dengan menggunakan media pembelajaran interaktif sebesar 85,15 lebih tinggi dibandingkan dengan siswa yang dibelajarkan dengan pembelajaran konvensional yaitu sebesar 76,91.

\section{PENUTUP}

Berdasarkan hasil penelitian, dan pembahasan maka dapat diperoleh beberapa kesimpulan sebagai berikut:
1. Hasil validasi dari ahli materi, ahli desain pembelajaran dan ahli media pembelajaran terhadap media pembelajaran interaktif pada mata pelajaran Pendidikan Kewarganegaraan (PKn) materi Dampak-damak Globalisasi yang dikembangkan dengan Software Macromedia Flash 6 menunujukkan bahwa keseluruhan rata-rata dikategorikan "Sangat Baik" setelah dilakukan beberapa revisi sehingga media tersebut dapat digunakan untuk uji coba selanjutnya. Hasil validasi dari uji coba perorangan, uji coba kelompok kecil, dan uji coba lapangan terbatas terhadap media yang dikembangkan dengan Software Macromedia Flash 6 termasuk dalam kategori "Sangat Baik" sehingga dapat diterima dan layak digunakan sebagai media belajar..

2. Penggunaan media pembelajaran interaktif lebih efektif dapat meningkatkan hasil belajar bila dibandingkan dengan pembelajaran konvensioanal. Rata-rata niali hasil belajar dengan pembelajaran menggunakan media pembelajaran interaktif Macromedia Flash diperoleh sebesar 85,15 lebih baik dari konvensionalnya sebesar 76,91.

\section{Implikasi}

Berdasarkan kesimpulan dan temuan penelitian, penelitian ini memiliki implikasi tinggi yang dapat digunakan guru dan peneitian lanjutan dalam proses pembelajaran. Adapun implikasi yang dimaksud adalah sebagai berikut:

1. Media yang dikembangkan ini akan memberikan sumbangan praktis terutama bagi guru dalam proses pelaksanaan pembelajaran, dimana media pembelajaran ini memberikan kemudahan dalam penyelenggaraan pembelajaran di kelas sehingga berdampak pada efektivitas pembelajaran dan dapat meningkatkan hasil belajar siswa. Dengan demikian media yang dikembangkan dapat dijadikan bahan pertimbangan bagi guru dalam menyampaikan materi Dampak-dampak Globalisasi.

2. Penerapan media pembelajaran berupa penggunaan media pembelajaran interaktif yang dikemas dalam bentuk dengan software macromedia flash 6 memerlukan kesiapan siswa untuk melaksanakan pembelajaran secara mandiri sehingga siswa akan memperoleh hasil belajar yang maksimal bila menerapkan media ini secara maksimal 
pula. Dengan menggunakan media, siswa diberi kesempatan untuk mengembangkan kreatifitasnya sebagai usaha mendalami materi pelajaran yang diberikan.

\section{Saran}

Berdasarkan hasil temuan yang telah diuraikan pada kesimpulan serta implikasi hasil penelitian, berikut ini diajukan beberapa saran yaitu:

1. Media pembelajaran interaktif pada mata pelajaran Pendidikan Kewarganegaraan adanya komputer sehingga hendaknya setiap siswa dibekali komputer PC atau notebook sesuai dengan kebutuhan.

2. Media pembelajaran interaktif ini adalah alat untuk membantu dalam proses penyampaian pembelajaran khususnya pada materi Dampak-dampak Globalisasi maka dari itu keberadaan guru masih sangat diperlukan sebagai fasilitator dan siswa tetap terlibat aktif dalam proses pembelajaran.

3. Agar hasil produk lebih maksimal dan layak digunakan lebih jauh lagi, maka diperlukan pengembangan yang terdiri dari: ahli pengembang kurikulum, ahli bidang studi dan ahli materi yang profesional, ahli media, dukungan dana, sarana dan waktu yang tersedia, dan kemampuan sarana-prasarana dalam produksi media yang memadai.

4. Pada Program Studi Teknologi Pendidikan hendaknya diadakan sarana dan prasarana yang mendukung mata kuliah produksi media yang bersifat pada produk dan adanya pembelajaran flash maupun software yang dapat digunakan untuk produksi media yang lainnya pada program studi teknologi pendidikan yang bertujuan untuk bekal dan mempermudah mahasiswa dalam proses pembuatan media pembelajaran interaktif (khususnya dalam penelitian R\&D berbasis TIK).

5. Dengan alasan keterbatasan waktu dan dana peneliti, sehingga masih banyak beberapa pengaruh-pengaruh yang belum terkontrol maka perlu kiranya dilakukan penelitian lebih lanjut pada sampel yang lebih representatif.

\section{DAFTAR PUSTAKA}

Abrianto, Danny \& Sitompul, Harun. 2014. Penggunaan Media Pembelajaran Berbasis Komputer Dan Sikap Inovatif Terhadap Hasil Belajar Teknologi Informasi Dan Komunikasi. Jurnal
Teknologi Informasi dan Komunikasi dalam Pendidikan. Vol. 1, No. 1, Juni 2014. Program Studi Teknologi Pendidikan UNIMED.

AECT. 1986. Defenisi Teknologi Pendidikan. Jakarta: Rajawali, terjemahan oleh Yusuf Hadi Miarso.

Arikunto, Suharsimi. 2013. Prosedur Penelitian Suatu Pendekatan Praktik, Jakarta: Rineka Cipta.

Arief, Sadiman, 2012. Media Pendidikan, Jakarta: Raja Grafindo Persada

Azhar, Arsyad. 2007. Media Pembelajaran, Jakarta: CV Rajawali.

Borg, W.R. \& Gall, M.D. Gall. 1983. Education Research: An Introduction, Fifth Edition. New York: Longman.

Berta, Dhewi. 2005. Macromedia Flash MX 2004. Yogyakarta: Andi Offset.

Dick, W \& Carey, JO. 2005. The Systematic Design of Instruction, Seventh Edition. New Jersey: Pearson

Djamarah, Saiful Bahri. 2011. Psikologi Belajar, Jakarta: Rineka Cipta

Gagne. 1985. The Cognitive Psychology of School Learning, Boston: Little Brown.

Hadiwijoyono, Harun. 1980. Sari Filsafat Barat. Yogyakarta: Kanisius.

Harjanto. 1997. Perencanaan Pengajaran. Jakarta: Rineka Cipta.

Harningsih, Angel \& Napitupulu, Efendi. 2014. Penggunaan Multimedia Pembelajaran Interaktif Dan Kreativitas Terhadap Hasil Belajar Teknologi Informasi dan Komunikasi (TIK). Jurnal Teknologi Informasi dan Komunikasi dalam Pendidikan. Vol. 1, No. 1, Juni 2014. Program Studi Teknologi Pendidikan UNIMED.

Hamid, K Abdul. 2014. Teori Belajar dan Pembelajaran. Medan: $r \quad$ Pasca Sarjana UNIMED.

Hasan, I.M. 2003. Pok eri Pendidikan Pancasila. aja Grafindo Persada.

Heinich, 1996. Instructional ......u and Technologies For Learning, Fifth Edition, America. Prenctice-Hall Inc.

Jhonson E.B 2011. Contextual Teaching and Learning (CTL) Menjadikan Kegiatan Belajar Mengajar Mengasyikkan Dan Bermakna. Bandung: Kaifa. Terjemahan oleh: Ibnu Setiawan. 
Kaelan, H. 2014. Pendidikan Pancasila. Yogyakarta: Paradigma

Kurniawan, Dedi. 2015 Pengembangan Media Interaktif Mata Pelajaran PKn Kelas X SMA Negeri 4 Kejuruan Muda Aceh Tamiang. Tesis. Program Pascasarjana UNIMED.

Miarso, Yusuf Hadi. 2004. Menyemai Benih Teknologi Pendidikan. Jakarta: Fajar Interpratama Mandiri.

Olson, Matthew H \& Hergenhahn, BR 2012. Theories of Learning, edisi ke tujuh. Jakarta : Kencana, terjemahan oleh Triwobowo BS.

Pramono, Andi. 2006. Presentasi Multimedia dengan Macromedia Flash. Yogyakarta: Andi Offset.

Prawiradilaga, Dewisalma \& Siregar, Eveline. 2004. Mozaik Teknologi Pendidikan. Jakarta: Kencana Prenada Group.

Prawiradilaga, Dewisalma. 2014. Wawasan Teknologi Pendidikan. Jakarta: Kencana Prenada Group.

Purnama, Pupung Budi. 2004. Membuat Animasi 3 Dimensi Macromedia Flash dengan Swift 3D. Jakarta: Elex Media Komputindo.

Reigeluth, Charles M. 1983. Instructional Design Theories and Models: An Overview of Their Current Status. Hilsdale, New Jersey: Lawrence Erlbaum Associates.

Rita, \& Situmorang, Julaga. 2014. Pengembangan Pembelajaran Multimedia Interaktif Berbasis Internet Pelajaran Bahasa Inggris. Jurnal Teknologi Informasi dan Komunikasi dalam Pendidikan. Vol. 1, No. 2, Desember 2014. Program Studi Teknologi Pendidikan UNIMED.

Rusman. 2012. Model-Model Pembelajaran, Mengembangkan Profesional Guru. Jakarta: Raja Grafindo Persada.

Sardiman. 2003. Interaksi dan Motivasi Belajar Mengajar. Jakarta: Raja Grafindo Persada

Schunk, Dale H. 2012. Teori-Teori Pembelajaran Persfektif Pendidikan.Yogyakarta: Pustaka Pelajar, Terjemahan oleh Eva Hamidah dkk.

Seels, Barbara B. Teknologi Pembelajaran Defenisi dan Kawasannya. Jakarta.

Setiawan, Deny. 2015. Kapita Selekta Kewarganegaraan. Medan: Larispa Indonesia.
Sihotang, Bangun \& Mursid. 2014. Penggunaan Multimedia Pembelajaran dan Kecerdasan Interpersonal Siswa Terhadap Hasil Belajar TUNE UP Motor Bensin. Jurnal Teknologi Informasi dan Komunikasi dalam Pendidikan. Vol. 1, No. 1, Juni 2014. Program Studi Teknologi Pendidikan UNIMED.

Slavin, Robert. 1995. Cooperative Learning: Theory Research and Practice. Buston. Allymand Bason Publisher, New York.

Somantri, N.M. 2001. Menggagas Pembaharuan Pendidikan IPS. Bandung:

PT Remaja Rosdakarya

Sudjana. 1992. Metode Statistik. Bandung: Tarsito.

Sugiyono. 2014. Metode Penelitian dan Pendidikan Pendekatan Kuantitatif, Kualitatif dan $R$ dan $D$. Bandung: Alfabeta.

Sumadi, Suryabrata. 2011. Psikologi Pendidikan. Jakarta: PT Raja Grafindo Persada.

Suparman, M Atwi. 2012. Desain Instruksional Modern, Jakarta: Erlangga.

Susilana, Rudi \& Riyanan, Cepi 2009. Media Pembelajaran, Hakikat, Pengembangan, Pemanfaatan Dan Penilaian, Bandung: Wacana Prima.

Surna, Inyoman \& Panderoit, Olga D. 2014. Psikologi Pendidikan 1. Jakarta : Erlangga.

Trianto. 2009. Mendesain Model Pembelajaran Inovatif-Progresif, Konsep, Landasan, dan Implementasinya pada Kurikulum Tingkat Satuan Pendidikan (KTSP). Jakarta: Kencana Prenada Media Group.

Uno, Hamzah B \& Lamatenggo, Nina. 2010. Teknologi Komunikasi dan Informasi Pembelajaran. Jakarta: Bumi Aksara.

Uno, Hamzah B \& Caesar Panjaitan. 2014. Variabel Penelitian dalam Pendidikan dan Pembelajaran. Jakarta: PT Ina Publikatama.

Undang-undang Republik Indonesia. Tentang Sistem Pendidikan Nasional. Nomor 20 Tahun 2003.

Wibowo, Eko Hadi. 2015. Flash Book: Tips dan Trik 21 Project Flash. Yogyakartaa: Andi Offset.

Winkel, W.S. 2014. Psikologi Pengajaran. Yogyakarta: Sketsa 
JURNAL TEKNOLOGI INFORMASI \& KOMUNIKASI dalam PENDIDIKAN, Vol.5 No.2, Desember 2018 p-ISSN; 2355-4983, e-ISSN: 2407-7488

Winarno, 2014. Pembelajaran Pendidikan Kewarganegaraan, isi, strategi, dan Penilaian. Jakarta: Bumi Aksara. 